\title{
Shellfishing and Human Evolution
}

Richard G. Klein

Program in Human Biology, Building 20, Inner Quad, Stanford University, Stanford, CA 94305 (email: rklein@stanford.edu) (corresponding author)

Douglas W. Bird

Department of Anthropology, 409 Carpenter Building, Pennsylvania State University, University Park, PA 16802 (email: dwb5537@psu.edu)

\section{Abstract}

Southern and northwestern Africa have provided the oldest known shell middens, dating from the Last Interglacial (MIS 5, 128 - 71 ka) and the early part of the succeeding glaciation (MIS 4, 71 - $59 \mathrm{ka}$ ). However, when and if older, suitably situated, stratified coastal sites are found, they are likely to show that routine shellfishing began much earlier, perhaps from the time that people first occupied coasts. Ethnohistoric records suggest that ancient people would have shellfished mainly during twice-monthly periods when the intertidal zone is maximally exposed. Caloric and nutrient return for coastal shellfishing effort can be quite high, but only when the intertidal is exposed, and archaeology implies that like ethnohistorically observed groups, ancient shellfish collectors depended more on terrestrial and marine vertebrates and on plants. Shellfishing can generate highly visible and durable archaeological signatures, and only a few collecting episodes each year could have produced the oldest middens, which span many millennia. Shell middens are so far unknown in European Neanderthal (Mousterian) and succeeding Upper Paleolithic sites, probably because suitably situated sites have yet to be found. Consistently large gastropod size in the oldest known middens suggests that human population growth cannot explain either the occasional presence of "symbolic" artifacts or the innovative burst that coincides with the spread of fully modern Africans to Eurasia 60-50 ka.

Keywords: Middle Stone Age, Later Stone Age, shellfishing, coastal foraging

\section{The Antiquity of Human Shellfishing}

Many species exploit intertidal shellfish, but only humans regularly transport them to variably distant open-air localities or rock shelters where repeated discard produces substantial shell heaps or middens. Open-air middens dating from the Present Interglacial [Marine Isotope Stage (MIS) 1], after 12-11 ka (thousands of years ago), dot lower and mid-latitude coasts everywhere. Older open-air middens are largely unknown, probably because most that formed during previous interglacials have failed to survive exposure to the elements, while those that formed during glacial intervals are mainly submerged on continental shelves. Near-coastal caves and rock shelters in southern Africa (Jacobs et al., 2008; Jerardino, 2016; Klein, 2009; Kyriacou et al., 2015; Langejans et al., 2012; Marean, 2014; Will et al., 2015) and in northwestern Africa (Campmas et al., 2015; Dibble et al., 2012; Steele, 2012; Steele and Alvarez-Fernández, 2011; Stoetzel et al., 2014) preserve middens that document central-place shellfishing during the Last Interglacial (MIS 5), between roughly 
128 and $71 \mathrm{ka}$. Although we can be sure that shellfishing continued through the Last Glaciation (MIS 4-2), between about 71 and $11 \mathrm{ka}$, coastal shelters rarely provide direct evidence, mostly because lower sea levels often displaced the coast $10 \mathrm{~km}$ or more from the shelters, beyond the usual daily range of most foragers.

Bajondillo Cave, Spain (Cortés-Sánchez et al., 2011), and Pinnacle Point Cave 13B, South Africa (Marean et al., 2007), suggest that people had begun shellfishing by 160-150 ka, during the latter part of the Penultimate Glaciation (MIS 6). However, near-coastal rock shelters with fills that formed during the Penultimate Glaciation are extremely rare and rock shelters with older fills are rarer yet, either because the shelters collapsed and their contents were eroded away or because high interglacial sea levels flushed their contents (Marean et al., 2014). The known record thus cannot show when people first shellfished, although the nutritive value of shellfish, the ease with which they can be collected, and the range of other terrestrial predators that take them (Carlton and Hodder, 2003; Erlandson and Moss, 2001) suggest that human exploitation began long before $160 \mathrm{ka}$, perhaps from the time when people first foraged near the water's edge. As discussed below, during periods when a low tide exposes the littoral, the high return rates from shellfishing would probably have made intertidal exploitation an especially attractive option to any near coastal, prehistoric humans. An accumulation of riverine mussel shells that antedates 500 ka from Trinil, Java (Joordens et al., 2015), may provide early evidence of shellfishing, although it was obtained in the 1890s without regard to context, and its human origin has been inferred only from uniform shell size and putative artificial shell modification. If the Trinil shells came from a midden, it appears to differ from nearly all much more recent middens in the absence of artifacts and vertebrate remains.

Figure 1 shows the approximate locations of all sites mentioned in the text.

\section{Proposed Connections between Shellfishing and Human Evolution}

Specialists have suggested that shellfishing was linked to human evolution in two key, possibly related ways. The first is that normal brain development and function require nutrients that are abundant in aquatic, especially coastal foods, including shellfish (Broadhurst et al., 1998; Broadhurst et al., 2002; Crawford et al., 2014; Cunnane, 2010; Cunnane and Crawford, 2014; Kyriacou et al., 2014; Parkington, 2001, 2003). The second is that coastal shellfishing is most productive when alignment of the moon and sun results in maximum diurnal exposure of the intertidal zone. Such times, known as "spring low tides", last about 3 days twice each month, coinciding with the new and full moons. In keeping with advance expectations, ethnographically observed coastal dwellers on the southern and southeastern coast of South Africa (Bigalke, 1973; Lasiak, 1992), and in Arnhem Land (Meehan, 1982) and the Meriam Islands (Bird et al., 2004), both northern Australia, exploited shellfish mainly during diurnal spring low tides. At other times people venturing into the intertidal zone will not only find fewer shellfish, they will also run greater risk of being swept away. Abundant 
shells in a coastal archaeological site might thus imply intellectual mastery of the tidal cycle (Marean, 2014).

The crucial nutrients that abound in the aquatic food chain are iron, iodine, and especially two omega-3, long-chain, polyunsaturated fatty acids, Docosahexaenoic acid (DHA) and Arachidonic acid. DHA in particular tends to be rare elsewhere, and it is a primary structural component of neural tissue (Brenna and Carlson, 2014). The evolution of the uniquely large and complex human brain could thus have required routine access to shellfish, fish, or other aquatic species. If this supposition is correct, intensive exploitation of aquatic foods must have begun by $300 \mathrm{ka}$, when relative to body mass, the human brain came to approximate its modern size (Ruff et al., 1997). The idea that the human brain evolved in an aquatic setting has passionate advocates among nutritionists, but it has failed to find much favor among paleoanthropologists, probably mostly because large, elaborate brains evolved in human populations everywhere, including ones with little or no access to aquatic foods. The implication is that there must be adequate terrestrial sources for the key fatty acids, perhaps mainly in the brains of terrestrial vertebrates, or that people, particularly pregnant women, can synthesize adequate quantities of DHA in the body (Carlson and Kingston, 2007a, b; Speth, 2012). In either case, the evolution of the human brain would not require aquatic foods, including shellfish.

We therefore focus here on the postulated link between shellfishing and human cognition. In a final section, we also address the human evolutionary implications of gastropod size in African Middle Stone Age (MSA) middens, dated between roughly 128 and $60 \mathrm{ka}$. Some MSA middens contain what are widely regarded as the world's oldest "symbolic" artifacts, anticipating much more compelling and abundant examples in the African Later Stone Age (LSA) and the coeval European Upper Paleolithic, after $50 \mathrm{ka}$. Fluctuating population size is probably the most popular explanation for why symbolic artifacts flicker in and out within the MSA, and population growth over the long MSA time span is often thought to explain the emergence of the LSA. However, extensive measurements we summarize below indicate that in average size, the gastropods in MSA middens are remarkably and unfailingly large. If we accept that larger gastropods imply fewer collectors, the conclusion must be that human populations remained consistently small from the beginning to the end of the MSA.

\section{Do Shell-Rich Sites Imply Mastery of the Tidal Cycle?}

At archaeological sites where intertidal shells abound, it is tempting to conclude that shellfish were central to human diet. However, ethnohistorically observed coastal foragers, even those who collected shellfish routinely, almost always depended more on other animal foods and on plants (Waselkov, 1987). In general, shellfish were most important seasonally when the efficiency of collection was high relative to other options, but even then they were not often the principal component of the diet [e.g. (Meehan, 1982)]. 
The indigenous people of the Meriam Islands provide a case in point (Bird and Bliege Bird, 1997; Bird et al., 2004). The collectors there are mainly women and children, who seek shellfish on both flat reefs and rocky shores. Twicemonthly on a few days surrounding the new and full moon, shellfishing offers substantial yields per hour, equal to or greater than the returns from terrestrial hunting and gathering reported in various foraging societies (De Vynck et al., 2016). Meriam women are especially sensitive to changes in return rates with tidal conditions, and rarely find it worthwhile to do any serious shellfishing outside of a two- to four-hour window of opportunity when the diurnal low spring tide exposes the mid-sub littoral zone of the intertidal. Then, larger gastropods (mostly conch) and bivalves (mostly tridacnid clams) are exposed and can be quickly collected and easily processed, offering very high returns of calories and nutrients. During the day, such conditions are more common from AprilSeptember, coinciding with the trade-winds which decrease offshore fishing opportunities and make reef flat collecting an especially attractive option. Overall, however, even though shellfishing repeatedly provides high returns and the results leave a large and distinctive material signature (Bird et al., 2002), traditional Meriam subsistence is based far more on turtles, fish, and gardening.

Experimental observation of experienced shellfish collectors on the south coast of South Africa (De Vynck et al., 2016) reveals essentially the same pattern seen on Mer. The collectors, who reported themselves to be descendants of the ancestral coastal Khoi-San population of the region, saw little point in shellfishing outside the 2-3-hour window on each of the two 2-4 day intervals that surround spring low tides each month. As with Meriam, during these intervals shellfishing was especially attractive: return rates were then high, but remained so only long enough to sustain Khoi-San families for a few days each month. Returns varied with the weather, meaning also with the season, since the weather tended to be most adverse in the winter months between June and September, when the people would especially need to rely on other resources.

The South African MSA coastal dwellers who produced what are usually considered the oldest-known true shell middens, dated between about 128 and $60 \mathrm{ka}$ at sites including the Klasies River Caves (Deacon and Deacon, 1999; Deacon and Wurz, 2005), Pinnacle Point Caves 13B and 5/6 (Jerardino et al., 2014; Marean, 2014; Marean et al., 2014), Blombos Cave (Henshilwood, 2005; Henshilwood et al., 2001; Langejans et al., 2012), Klipdrift Shelter (Henshilwood et al., 2014), and Ysterfontein 1 Shelter (Avery et al., 2008; Wurz, 2012), discarded not only numerous shells, but also thousands of bones from terrestrial mammals and fur seals. The especially rich Klasies River Caves are in fact probably much better known for their extensive mammalian fauna than for their shellfish (Bartram and Marean, 1999; Binford, 1984; Klein, 1976, 1989; Outram, 2001; Turner, 1989). In addition to mammals, the MSA inhabitants of Klasies River and other coastal sites accumulated numerous seabirds (Avery, 1990), particularly penguins and cormorants, and MSA people on the drier western stretches of the coastal zone also focused heavily on tortoises (Steele and Klein, 2005/06; Thompson and Henshilwood, 2014). At Ysterfontein 1, in what was probably an exceptionally arid area, they frequently collected ostrich eggs (Avery 
et al., 2008). No MSA coastal site preserves the plant component of the diet, but laterally extensive carbonized plant residues within the deeply stratified sequence at Klasies River testify to the importance of vegetal foods, probably mainly geophytes (Deacon and Deacon, 1999). With ethnohistoric observations in mind then, it is reasonable to suppose that South African MSA people foraged near the coast primarily for terrestrial vertebrates, seals, seabirds, and plants and focused on shellfish only when conditions were such that intertidal collecting was especially fruitful. Only later did the LSA coastal successors to MSA people add fish to the list of primary resources. LSA inventions, including fish gorges and net sinkers (Deacon, 1984), help explain the abundance of fish bones in LSA sites.

In the introduction, we noted that the rarity or absence of stratified coastal sites antedating MIS 5 may always make it difficult to determine when stone age people began shellfishing routinely, but whenever this was, ethnography and archaeology provide no reason to suppose that shellfish were ever central to ancient diets. This is mainly because shellfishing provides high returns for only a few hours twice each month, and to meet their subsistence needs, prehistoric coastal dwellers therefore had to focus more on other resources. It follows that they would have had little incentive to master seasonal and monthly details of the tidal cycle, although they could have observed phases of the moon to determine when returns from shellfishing would be particularly great. Again, the Meriam provide a case in point: while they of course know lunar and seasonal tidal cycles well, they do not need this knowledge to schedule shellfishing; all they need to know is what the moon looks like tonight to know what the tide will do tomorrow. And as with Meriam, prehistoric shellfishers may also have keyed in on changes in the odor borne by on-shore breezes. When they foraged near the coast for plants or other sessile resources, the main collectors could have snacked on shellfish high on the shore throughout the tidal cycle, and they would naturally have moved down the shore when the opportunity arose and other more highly ranked foods became temporarily less attractive.

Over the millennia during which the ancient South African middens formed, only a few collecting episodes each year could account for their abundant shells. More frequent collection could have depleted local gastropod populations for years, since many species grow slowly and they lack subtidal backups from which to recolonize the intertidal zone. Foragers who faced diminishing returns of shellfish stocks devised various compensatory strategies (Thomas, 2015) that also conserved vital terrestrial assets. In the absence of institutionalized territoriality, their most common tactic was probably to move along the coast to a fresh locale or sometimes to a seasonally more rewarding inland setting (Codding et al., 2014). We have no information on MSA movements, but stableisotope readings on Holocene LSA human bones from the same South African coasts that have provided MSA middens suggest that the LSA people rarely moved inland and conversely that immediately adjacent inland groups rarely visited the coast (Sealy, 2006; Sealy and Pfeiffer, 2000; Sealy et al., 1986). The coastal foragers mainly ate a mix of terrestrial foods and lower-trophic level marine species, probably both line fish and shellfish, but at one locality, they also 
frequently consumed numerous high-trophic level marine predators, probably mostly fur seals but also possibly large carnivorous fish.

\section{Did the Neanderthals Shellfish Routinely?}

Since shellfishing can be highly rewarding when the intertidal is exposed, it is reasonable to ask what role it may have played among other recent members of our genus. The Mousterian site of Bajondillo Cave, southern Spain, noted in the introduction, implies that Neanderthals collected shellfish, at least occasionally, by $150 \mathrm{ka}$. This date approximates the age of the oldest-known evidence for shellfish collecting in South Africa, at Pinnacle Point Cave 13B. Younger Mousterian sites, including Üçağızlı Cave II, Turkey (Stiner, 2009); Moscerini Cave, Italy (Stiner, 1993); los Aviones Cave (Montes, 1991; Zilhão et al., 2010) and Perneras Cave (Carrión et al., 1999; Montes, 1988), Spain; Devil's Tower, Vanguard Cave and Gorham's Cave, Gibraltar (Barton, 2000; Stringer et al., 2008); and Ibn Ammar and Figuiera Brava Caves, Portugal (Bicho and Haws, 2008; Haws et al., 2011) have also provided intertidal shells. Moscerini, Vanguard, Gorham's, and Ibn Ammar caves are further notable for a few bones of marine vertebrates. Neanderthals introduced shells to Moscerini Cave and Üçağızlı II mostly during MIS 5, between roughly 115 and $70 \mathrm{ka}$. They introduced shells elsewhere during MIS 3 , at a time or times between about 55 and $\geq 32 \mathrm{ka}$, depending on the site. However, at each site, the shells tend to be dispersed through the deposit, and there are no true shell middens like those that mark the South African MSA coastal caves noted in the last section. Since MSA people were anatomically near-modern, the absence of Neanderthal shell middens might reflect more limited Neanderthal ability to understand the relationship between phases of the moon and the especially low tides when shellfish collection would be most productive and least dangerous (Marean, 2014).

One problem with this idea is that in every other detectable behavioral respect, including a refined ability to flake stone, the use of naturally occurring pigments, burial of the dead, control of fire, the ability to synthesize pitch adhesive from bark, and even the occasional manufacture of putative symbolic artifacts, the Neanderthals were as derived behaviorally as their more modernlooking MSA contemporaries (d'Errico and Stringer, 2011; Roebroeks and Soressi, 2016; Villa and Roebroeks, 2014). It thus seems more likely that known Neanderthal (Mousterian) site locations explain why archaeologists have yet to find Neanderthal shell middens. The best known Neanderthal coastal or nearcoastal sites in fact occur on the northern margin of the Mediterranean Sea, where the intertidal zone tends to be narrow owing to a small tidal range and where intertidal waters tend to be nutrient-poor owing to weak upwelling and limited continental runoff (Colonese et al., 2011; Fa, 2008). These factors restrict molluscan biomass and productivity, and together with depressed sea levels that displaced coastlines seawards, they probably explain why shell middens are rare even in Mediterranean coastal sites occupied by the fully modern Upper Paleolithic successors to the Neanderthals (Bailey and Flemming, 2008; Colonese et al., 2011). 
Shellfish enjoy much more favorable intertidal conditions on the Atlantic coasts of Europe, but even there, middens are essentially unknown until sea levels rose and coastlines began to approximate historic ones in the terminal Upper Paleolithic/Mesolithic, after 14-13 ka (Gutiérrez-Zugasti, 2011; GutiérrezZugasti et al., 2013). Intertidal shells, mostly limpets, are common in Upper Paleolithic layers within and downslope of the Vale Boi rockshelter (Gravettian through early Magdalenian, ca. 28-18 ka), Portugal (Manne et al., 2012), and in some Upper Paleolithic caves or rockshelters in Cantabrian Spain, including El Cuco (Aurignacian and Gravettian, ca. 34-28 ka) (Gutiérrez-Zugasti et al., 2013), La Riera (Solutrean and Magdalenian, ca. 24-14 ka) (Straus and Clark, 1986, 2014), and El Juyo (Magdalenian, ca. 16 ka) (Freeman et al., 1988). However, at each site, the deposits are more "strata with shells" than "true shell middens" (Gutiérrez-Zugasti, 2011), and the shells are overshadowed by bones from red deer and other mammals.

When the various Upper Paleolithic sites were occupied, they were mostly too far from the shore for shell middens to accumulate even if the occupants relied to some extent on shellfish. And Mousterian sites that were as close or closer to the shore, remain largely unknown. Since Upper Paleolithic sites are much more common than Mousterian sites in western Europe (Mellars and French, 2011) and Upper Paleolithic sites that date between roughly 24 and 14 ka are particularly well known on the Atlantic seaboard (Straus et al., 2000), the absence of Upper Paleolithic middens increases the likelihood that Mousterian middens are lacking because suitably situated sites have yet to be found, not because Neanderthals were cognitively less sophisticated than MSA South Africans.

Due to transport constraints, midden remnants are likely to be tethered closely to the coast, and thus, especially along procumbent shorelines, a small rise in sea level will erase most signatures of routine shellfishing. Again, the contemporary Meriam case provides some insight. While collecting in the intertidal, foragers quickly reach a point where they must decide to either cull meat from bulky shell, or transport unprocessed loads to a central locale for processing and consumption. Meriam women adjust their shellfishing strategies relative to load transport distance and the costs and benefits of field processing different types of shellfish. As a result, they rarely transport the shells of the most important mollusks back to a midden if the base is located much more than a kilometer from the site of procurement (Bird and Bliege Bird, 1997). The shells of some of the less important species are much more likely to be transported in bulk, thus systematically biasing the assemblage in the middens (Bird et al., 2002). It is not surprising that intertidal shellmiddens are thus fastened to shorelines, and that in Europe they are very rare until sea level rise during the Pleistocene/Holocene transition brought shorelines to near their historic positions. Dense middens dating to the last glacial maximum and earlier would accumulate and survive only on coasts where the offshore profile was steep.

Islands between Sunda (southeasternmost Asia and its continental shelf) and Sahul (conjoined Australia, New Guinea, and Tasmania), together with 
Melanesian islands to the east of New Guinea illustrate the importance of steep shorelines for documenting glacial-age shellfish collecting. There is no evidence so far that the regional contemporaries of the Neanderthals produced middens, but with the arguable exception of Flores (Brown, 2012; Henneberg et al., 2014; Sutikna et al., 2016), there is no compelling evidence that people occupied any of the islands or Sahul before modern humans appeared regionally between 50 and $45 \mathrm{ka}$ (O'Connell and Allen, 2015). Thereafter, steep offshore profiles, for example on Timor (O'Connor, 2007) and New Ireland (Allen et al., 1988), meant that sites remained near the coast even when sea level fell dramatically, and in contrast to Europe, middens are relatively well known from as long ago as $40 \mathrm{ka}$ (O'Connell and Allen, 2012; Szabó and Amesbury, 2011).

\section{Gastropod Size and Later Human Evolution in Africa}

Paleoanthropologists now mostly agree that one or more subgroups of modern humans expanded from Africa to populate the rest of the world beginning 60-50 ka, broadly coinciding with the MSA/LSA transition. Archaeologists commonly attribute the expansion to significant behavioral change and many see initial flickers of this change in South African MSA sites before $60 \mathrm{ka}$. The key sites are Blombos Cave, where deposits assigned to the Still Bay Variant of the MSA have provided abstractly incised fragments of ocher (Henshilwood et al., 2009) and perforated tick shell "beads" (d'Errico et al., 2005; Henshilwood et al., 2004), and Diepkloof Rockshelter (Parkington et al., 2005; Texier et al., 2010) and Klipdrift Shelter (Henshilwood et al., 2014), where deposits assigned to the Howieson's Poort Variant contain fragments of engraved ostrich eggshell. The sequences at Diepkloof (Porraz et al., 2013) and at Sibudu Cave (Wadley, 2007) show that the Still Bay antedates the Howieson's Poort and that other MSA variants existed in between. Neither the intervening variants nor those that follow the Howieson's Poort have produced "symbolic" artifacts (Lombard and Parsons, 2011). Optically Stimulated Luminescence (OSL) dating has provided ages for the Still Bay (Jacobs et al., 2013) and the Howieson's Poort (Jacobs et al., 2008) whose accuracy and precision may have been overstated (Guérin et al., 2013). Nonetheless, in company with faunal and sedimentological observations, the OSL dates suggest that the Still Bay existed for perhaps six thousand years around 80 ka during the latter part of MIS 5 and that the Howieson's Poort existed for a comparable period around 70 ka during the MIS 5/4 transition (Deacon, 1989, 2001). Both variants thus antedate the LSA and the expansion of fully modern Africans to Eurasia 60-50 ka.

The incised ocher fragments and shell beads are not as obviously symbolic or artistic as many items of art and jewelry that postdate 50-40 ka in both Africa and Eurasia. The engraved ostrich eggshell fragments are more persuasive, but they require direct radiocarbon dating to show that they are in place in the Howieson's Poort layers, since at both Diepkloof Shelter and Klipdrift Shelter, they occur almost entirely within $50 \mathrm{~cm}$ of the present surface and ethnohistoric observations indicate that LSA people buried ostrich eggshell canteens for later retrieval (Henderson, 2002; Morris, 1994; Rudner, 1953; Schapera, 1930). However, if we accept all the proposed symbolic artifacts at face value, we need 
to explain why symbolism was initially restricted to the Still Bay and the Howieson's Poort Variants of the MSA and why it flowered continuously only from the time of the MSA/LSA interface after about 50 ka (d'Errico et al., 2012; Villa et al., 2012). The most popular explanation is probably that Still Bay and Howieson's Poort populations were unusually large by MSA standards and that early LSA populations were larger still. The logic is that larger populations will contain more potential innovators and that they are less likely to lose innovations by chance alone (Henrich, 2004; Powell et al., 2009; Richerson et al., 2009). This argument is problematic (Vaesen et al., 2016), but whether or not it is accepted, shellfishing is relevant for understanding MSA/LSA differences in population and subsistence because the average size of rocky intertidal gastropod species in MSA and LSA coastal middens probably reflects the number of human collectors. This follows from the assumption that smaller average size in any given gastropod species implies more intense collection, and more intense collection is most readily attributed to growth in collector numbers. Archaeologists interpreting declining shellfish size elsewhere in the world have often proceeded from this assumption (Allen et al., 1988; Braje et al., 2012; Erlandson et al., 2011; Erlandson et al., 2008; Gutiérrez-Zugasti, 2011; McCoy, 2008; Thangavelu et al., 2011).

Measurements on economically important Cape turban shells and limpets from MSA and LSA middens along the south and west coasts of South Africa show that in every species examined, MSA specimens average consistently and significantly larger than those in succeeding LSA middens (Avery et al., 2008; Klein and Steele, 2013). MSA middens also contain a smaller range of gastropod species, together with smaller numbers of the smaller species that occur in both MSA and LSA middens (De Vynck et al., 2016; Parkington, 2003). The most economic explanation is that less numerous MSA collectors more often bypassed food items associated with lower post-encounter return rates. In large gastropod size and limited species diversity, Still Bay and Howieson's Poort middens that contain symbolic artifacts mirror MSA middens that lack them, and regardless of MSA variant, the MSA middens always differ from LSA middens that formed under comparable interglacial conditions.

The MSA middens span the Last Interglacial (MIS 5), from perhaps 128 to $71 \mathrm{ka}$, while the LSA middens date entirely from MIS 1 (the Holocene) from about $12 \mathrm{ka}$ to near present. Older LSA middens are probably lacking, because they formed mainly on the now drowned continental shelf. This means that gastropod size cannot be used to test for population increase when the LSA began, although the simultaneous Out-of-Africa expansion suggests an LSA population surge. Somewhat less arid climate in northeast Africa and lower sea levels may have facilitated the expansion (Eriksson et al., 2012). The important point here is that the available gastropod size data imply that whatever the cognitive implications of symbolic MSA artifacts, human fitness, defined as the ability to survive and reproduce, was not enhanced. MSA populations, including those that produced Still Bay and Howieson's Poort artifacts, appear to have been consistently small, and based on gastropod size, MSA populations did not grow through time. Progressively smaller gastropods would be predicted if population 
growth underlies the behavioral innovations that ushered in the succeeding LSA. Alternatively, these innovations could reflect chance genetic change that boosted human ability to innovate (Klein, 2009). Genomic comparisons between modern humans and Neanderthals hint at this possibility (Green et al., 2010), and a direct test may become possible when the genome of near-modern MSA Africans is recovered. Indications that Neanderthals transferred a tiny number of genes to modern Eurasians would not cloud the result, since none of the genes bear on cognition (Sankararaman et al., 2014).

\section{Summary and Conclusion}

Pinnacle Point Cave 13B, South Africa and Bajondillo Cave, Spain show that human shellfishing began at least 160-150 ka, during the Middle Stone Age (MSA) in Africa and the coeval Mousterian in Europe. In both Africa and Eurasia, stratified coastal occupation sites that demonstrably antedate $160-150$ ka remain unknown and may always be rare, because high interglacial sea levels or cave collapse have mostly flushed or destroyed older coastal cave fills. However, ethnohistoric observations show that shellfishing requires little specialized knowledge, technology, or bodily risk, so long as it is conducted mainly during twice-monthly intervals of low tide that can be observed from the shore. Shellfishing by numerous nonhuman species underscores this conclusion. In sum, the nutritive value and easy accessibility of shellfish imply that when coastal occupation sites older than 160-150 ka are found, they will likely reveal yet earlier shellfishing, perhaps from the time that people first occupied sea coasts.

So far, South African coastal caves dating primarily to the Last Interglacial (MIS 5), between roughly 128 and $71 \mathrm{ka}$, have provided the oldest most compelling evidence for routine, repeated shellfish collection. The shells at each site tend to be as densely packed as they are in the much later prehistoric middens that sprinkle the coasts of every inhabited continent, and they thus imply a broadly comparable, if much older interest in central-place shellfishing. Globally, only northwestern Africa has provided comparably ancient compelling evidence for routine shellfishing. In both southern and northwestern Africa, the people were near-modern humans, close to, if not on the line that produced the fully modern people who expanded from Africa, beginning 60-50 ka. This raises the possibility that near-modern Africans were the first to understand that shellfishing is most productive and least dangerous during a few days twice each month when the lunar cycle results in maximum exposure of the intertidal zone and thus that they were the first to collect shellfish intensively. However, to determine when the intertidal will be maximally accessible, even much earlier people would probably have realized that they needed only to look up at the moon or to monitor the odor from on-shore breezes. For brief periods each month, they could then have obtained substantial nutritional returns from shellfish, but most of the time, when the intertidal was much less exposed, they would have had to meet their needs almost entirely from other sources, principally vertebrates and plants. Both ethnohistoric observations and midden content imply that this is what the ancient South Africans did. The abundance of shells in their middens does not imply that they relied especially on shellfish, and 
over the millennia when the middens formed, only a few collecting episodes each year could have produced the mass of shells that we see now.

Archaeology shows that the Neanderthal contemporaries of MSA Africans sometimes obtained shellfish, but so far, no Neanderthal (Mousterian) site has provided a midden like those at contemporaneous coastal MSA sites. The reason could be that unlike MSA Africans, the Neanderthals failed to understand the relationship between the phases of the moon and the tides. However, middens are equally rare in sites of the fully modern Upper Paleolithic Europeans whose roots lie in MSA Africa and who succeeded the Neanderthals after $50 \mathrm{ka}$. The oldest known European middens date only from the terminal Upper Paleolithic and Mesolithic after about $14 \mathrm{ka}$, and it seems likely that earlier Upper Paleolithic examples are so far unknown because appropriately situated sites remain unknown, not because earlier Upper Paleolithic people (and the Neanderthals before them) collected shellfish less intensively than MSA Africans. In both Europe and Africa, most middens that formed between 60 and $14 \mathrm{ka}$ are probably on the now-drowned continental shelves.

The gastropods that abound in South African MSA and succeeding Later Stone Age (LSA) sites provide an opportunity to determine whether sporadically larger human population size explains the flickering of precocious, LSA-like symbolic behavior in two MSA phases and whether long-term population increase over the course of the MSA could explain the emergence of the LSA, roughly $50 \mathrm{ka}$. The underlying logic is that more intensive gastropod collection reduces average gastropod size, and more intensive collection is likely to reflect a greater number of human collectors. Measurements of multiple economically important gastropod species on both the southern and western coasts of South Africa show that MSA specimens are consistently and significantly larger on average than their LSA counterparts. On average, gastropods are as large in MSA middens with precocious, "symbolic" artifacts as in middens without, which means that if the artifacts imply enhanced cognitive capacity, this was not associated with larger human populations. There is also no tendency for average gastropod size to decline over time during the MSA, which reduces the likelihood that population growth triggered the LSA. In this light, other explanations for LSA innovations, perhaps above all chance genetic change that enhanced human ingenuity, deserve consideration.

\section{Acknowledgements}

We thank Graham Avery, Antonieta Jerardino, John Speth, Teresa Steele, Lawrence Straus, and an anonymous reviewer for comments on a draft and the National Science Foundation for research support. DWB owes a great deal to the Meriam community for their many years of friendship and support. 


\section{References}

Allen, J., Gosden, C., Jones, R., White, J.P., 1988. Pleistocene dates for the human occupation of New Ireland, northern Melanesia. Nature 331, 707709.

Avery, G., 1990. Avian Fauna, Palaeoenvironments and Palaeoecology in the Late Quaternary of the Western and Southern Cape, South Africa, Department of Archaeology. University of Cape Town, Cape Town, p. 206.

Avery, G., Halkett, D., Orton, J., Steele, T.E., Tusenius, M., Klein, R.G., 2008. The Ysterfontein 1 Middle Stone Age Rockshelter and the evolution of coastal foraging. S Afr Archaeol Soc Goodwin Ser 10, 66-89.

Bailey, G.N., Flemming, N.C., 2008. Archaeology of the continental shelf: Marine resources, submerged landscapes and underwater archaeology. Quaternary Sci Rev 27, 2153-2165.

Barton, R.N.E., 2000. Mousterian hearths and shellfish: late Neanderthal activities on Gibraltar, in: Stringer, C.B., Barton, R.N.E., Finlayson, J.C. (Eds.), Neanderthals on the Edge. Oxbow Books, Oxford, pp. 211-220.

Bartram, L.E., Marean, C.W., 1999. Explaining the "Klasies Pattern": Kua ethnoarchaeology, the Die Kelders Middle Stone Age archaeofauna, long bone fragmentation and carnivore ravaging. J Archaeol Sci 26, 9-20.

Bicho, N., Haws, J., 2008. At the land's end: marine resources and the importance of fluctuations in the coastline in the prehistoric huntergatherer economy of Portugal. Quaternary Sci Rev 27, 2166-2175.

Bigalke, E.H., 1973. The exploitation of shellfish by coastal tribesmen of the Transkei. Ann. Cape Prov. Mus. (nat. Hist.) 9, 159-175.

Binford, L.R., 1984. Faunal Remains from Klasies River Mouth. Academic Press, Orlando, FL.

Bird, D.W., Bliege Bird, R.L., 1997. Contemporary shellfish gathering strategies among the Meriam of the Torres Strait Islands, Australia: Testing predictions of a Central Place Foraging model. J Archaeol Sci 24, 39-63.

Bird, D.W., Bliege Bird, R.L., Richardson, J.L., 2004. Meriam ethnoarchaeology: shellfishing and shellmiddens. Memoirs of the Queensland Museum, Cultural Heritage Series (Brisbane) 3, 183-197.

Bird, D.W., Richardson, J.L., Veth, P.M., Barham, A.J., 2002. Explaining shellfish variability in middens on the Meriam Islands, Torres Strait, Australia. J Archaeol Sci 29, 457-469.

Braje, T.J., Rick, T.C., Erlandson, J.M., 2012. A trans-Holocene historical ecological record of shellfish harvesting on California's Northern Channel Islands. Quatern Int 264, 109-120.

Brenna, J.T., Carlson, S.E., 2014. Docosahexaenoic acid and human brain development: Evidence that a dietary supply is needed for optimal development. J Hum Evol 77, 99-106.

Broadhurst, C.L., Cunnane, S.C., Crawford, M.A., 1998. Rift Valley lake fish and shellfish provided brain-specific nutrition for early Homo. British Journal of Nutrition 79, 3-21.

Broadhurst, C.L., Wang, Y., Crawford, M.A., Cunnane, S.C., Parkington, J.E., Schmidt, W.F., 2002. Brain-specific lipids from marine, lacustrine, or 
terrestrial food resources: potential impact on early African Homo sapiens. Comparative Biochemistry and Physiology Part B: Biochemistry and Molecular Biology 131, 653-673.

Brown, P., 2012. LB1 and LB6 Homo floresiensis are not modern human (Homo sapiens) cretins. J Hum Evol 62, 201-224.

Campmas, E., Michel, P., Costamagno, S., Amani, F., Stoetzel, E., Nespoulet, R., El Hajraoui, M.A., 2015. Were Upper Pleistocene human/non-human predator occupations at the Témara caves (El Harhoura 2 and El Mnasra, Morocco) influenced by climate change? J Hum Evol 78, 122-143.

Carlson, B.A., Kingston, J.D., 2007a. Docosahexaenoic acid biosynthesis and dietary contingency: Encephalization without aquatic constraint. Am J Hum Bio 19, 585-588.

Carlson, B.A., Kingston, J.D., 2007b. Docosahexaenoic acid, the aquatic diet, and hominin encephalization: Difficulties in establishing evolutionary links. Am J Hum Bio 19, 132-141.

Carlton, J.T., Hodder, J., 2003. Maritime mammals: terrestrial mammals as consumers in marine intertidal communities. Mar Ecol-Prog Ser 256, 271286.

Carrión, J.S., Munuera, M., Navarro, C., Burjachs, F., Dupré, M., Walker, M.J., 1999. The palaeoecological potential of pollen records in caves: the case of Mediterranean Spain. Quaternary Sci Rev 18, 1061-1073.

Codding, B.F., O'Connell, J.F., Bird, D.W., 2014. Shellfishing and the colonization of Sahul: A multivariate model evaluating the dynamic effects of prey utility, transport considerations and life-history on foraging patterns and midden composition. The Journal of Island and Coastal Archaeology 9, 238-252.

Colonese, A.C., Mannino, M.A., Bar-Yosef Mayer, D.E., Fa, D.A., Finlayson, J.C., Lubell, D., Stiner, M.C., 2011. Marine mollusc exploitation in Mediterranean prehistory: An overview. Quatern Int 239, 86-103.

Cortés-Sánchez, M., Morales-Muñiz, A., Simón-Vallejo, M.D., Lozano-Francisco, M.C., Vera-Peláz, J.L., Finlayson, C., Rodríguez-Vidal, J., DelgadoHuertas, A., Jiménez-Espejo, F.J., Martínez-Ruiz, F., Martínez-Aguirre, M.A., Pascual-Granged, A.J., Bergadà-Zapata, M.M., Gibaja-Bao, J.F., Riquelme-Cantal, J.A., López-Sáez, J.A., Rodrigo-Gámiz, M., Sakai, S., Sugisaki, S., Finlayson, G., Fa, D.A., Bicho, N.F., 2011. Earliest known use of marine resources by Neanderthals. PLoS One 6, e24026.

Crawford, M.A., Broadhurst, C.L., Cunnane, S., Marsh, D.E., Schmidt, W.F., Brand, A., Ghebremeskel, K., 2014. Nutritional armor in evolution: Docosahexaenoic Acid as a determinant of neural evolution and hominid brain development. Mil. Med. 179, 61-75.

Cunnane, S.C., 2010. Human brain evolution: a question of solving key nutritional and metabolic constraints on mammalian brain development, in: Cunnane, S.C., Stewart, K.M. (Eds.), Human Brain Evolution: The Influence of Freshwater and Marine Food Resources. Wiley-Blackwell, Hoboken, NJ, pp. 33-64. 
Cunnane, S.C., Crawford, M.A., 2014. Energetic and nutritional constraints on infant brain development: Implications for brain expansion during human evolution. J Hum Evol 77, 88-98.

d'Errico, F., Backwell, L., Villa, P., Degano, I., Lucejko, J.J., Bamford, M.K., Higham, T.F.G., Colombini, M.P., Beaumont, P.B., 2012. Early evidence of San material culture represented by organic artifacts from Border Cave, South Africa. Proc Natl Acad Sci USA 109, 13214-13219.

d'Errico, F., Henshilwood, C.S., Vanhaeren, M., van Niekerk, K.L., 2005. Nassarius kraussianus shell beads from Blombos Cave: evidence for symbolic behaviour in the Middle Stone Age. J Hum Evol 48, 3-24.

d'Errico, F., Stringer, C.B., 2011. Evolution, revolution or saltation scenario for the emergence of modern cultures? Philos T Roy Soc B 366, 1060-1069.

De Vynck, J.C., Anderson, R., Atwater, C., Cowling, R.M., Fisher, E.C., Marean, C.W., Walker, R.S., Hill, K., 2016. Return rates from intertidal foraging from Blombos Cave to Pinnacle Point: Understanding early human economies. J Hum Evol 92, 101-115.

Deacon, H.J., 1989. Late Pleistocene paleoecology and archaeology in the southern Cape, South Africa, in: Mellars, P.A., Stringer, C.B. (Eds.), The Human Revolution: Behavioural and Biological Perspectives on the Origins of Modern Humans. Edinburgh University Press, Edinburgh, pp. 547-564.

Deacon, H.J., 2001. Guide to Klasies River 2001. Stellenbosch University, Stellenbosch.

Deacon, H.J., Deacon, J., 1999. Human Beginnings in South Africa: Uncovering the Secrets of the Stone Age. David Philip, Cape Town.

Deacon, H.J., Wurz, S., 2005. A Late Pleistocene archive of life at the coast, Klasies River, in: Stahl, A.B. (Ed.), African Archaeology: A Critical Introduction. Blackwell, Oxford, pp. 213-228.

Deacon, J., 1984. The Later Stone Age of southernmost Africa. Brit Archaeol Rep In 213, 1-441.

Dibble, H.L., Aldeias, V., Alvarez-Fernández, E., Blackwell, B., Hallett-Desguez, E., Jacobs, Z., Goldberg, P., Lin, S.C., Morala, A., Meyer, M.C., Olzsewski, D.I., Reed, K., Reed, D., Rezek, Z., Richter, D., Roberts, R.G., Sandgathe, D., Schurmans, U., Skinner, A.R., Steele, T.E., El-Hajraoui, M., 2012. New excavations at the site of Contrebandiers Cave, Morocco. Paleoanthropology, 145-201.

Eriksson, A., Betti, L., Friend, A.D., Lycett, S.J., Singarayer, J.S., von CramonTaubadel, N., Valdes, P.J., Balloux, F., Manica, A., 2012. Late Pleistocene climate change and the global expansion of anatomically modern humans. Proc Natl Acad Sci USA 109, 16089-16094.

Erlandson, J.M., Braje, T.J., Rick, T.C., Jew, N.P., Kennett, D.J., Dwyer, N., Ainis, A.F., Vellanoweth, R.L., Watts, J., 2011. 10,000 years of human predation and size changes in the owl limpet (Lottia gigantea) on San Miguel Island, California. J Archaeol Sci 38, 1127-1134.

Erlandson, J.M., Moss, M.L., 2001. Shellfish feeders, carrion eaters, and the archaeology of aquatic adaptations. Am Antiq 66, 413-432. 
Erlandson, J.M., Rick, T.C., Braje, T.J., Steinberg, A., Vellanoweth, R.L., 2008. Human impacts on ancient shellfish: a 10,000 year record from San Miguel Island, California. J Archaeol Sci 35, 2144-2152.

Fa, D.A., 2008. Effects of tidal amplitude on intertidal resource availability and dispersal pressure in prehistoric human coastal populations: the Mediterranean-Atlantic transition. Quaternary Sci Rev 27, 2194-2209.

Freeman, L.G., González Echegaray, J., Klein, R.G., Crowe, W.T., 1988. Dimensions of research at El Juyo: an earlier Magdalenian site in Cantabrian Spain, in: Dibble, H.L., Montet-White, A. (Eds.), Upper Pleistocene prehistory of Western Eurasia. The University Museum, University of Pennsylvania, Philadelphia, pp. 3-39.

Green, R.E., Krause, J., Briggs, A.W., Maricic, T., Stenzel, U., Kircher, M., Patterson, N., Li, H., Zhai, W., Fritz, M.H.-Y., Hansen, N.F., Durand, E.Y., Malaspinas, A.-S., Jensen, J.D., Marques-Bonet, T., Alkan, C., Prufer, K., Meyer, M., Burbano, H.A., Good, J.M., Schultz, R., Aximu-Petri, A., Butthof, A., Hober, B., Hoffner, B., Siegemund, M., Weihmann, A., Nusbaum, C., Lander, E.S., Russ, C., Novod, N., Affourtit, J., Egholm, M., Verna, C., Rudan, P., Brajkovic, D., Kucan, Z., Gusic, I., Doronichev, V.B., Golovanova, L.V., Lalueza-Fox, C., de la Rasilla, M., Fortea, J., Rosas, A., Schmitz, R.W., Johnson, P.L.F., Eichler, E.E., Falush, D., Birney, E., Mullikin, J.C., Slatkin, M., Nielsen, R., Kelso, J., Lachmann, M., Reich, D., Paabo, S., 2010. A draft sequence of the Neandertal genome. Science 328, 710-722.

Guérin, G., Murray, A.S., Jain, M., Thomsen, K.J., Mercier, N., 2013. How confident are we in the chronology of the transition between Howieson's Poort and Still Bay? J Hum Evol 64, 314-317.

Gutiérrez-Zugasti, I., 2011. Coastal resource intensification across the Pleistocene-Holocene transition in Northern Spain: Evidence from shell size and age distributions of marine gastropods. Quatern Int 244, 54-66.

Gutiérrez-Zugasti, I., Cuenca-Solana, D., Rasines del Río, P., Muñoz, E., Santamaría, S., Morlote, J.M., 2013. The role of shellfish in huntergatherer societies during the Early Upper Palaeolithic: A view from El Cuco rockshelter, northern Spain. J Anthropol Archaeol 32, 242-256.

Haws, J.A., Funk, C.L., Benedetti, M.M., Bicho, N.F., Daniels, J.M., Minckley, T.A., Denniston, R.F., Jeraj, M., Gibaja, J.F., Hockett, B.S., Forman, S.L., 2011. Paleolithic landscapes and seascapes of the west coast of Portugal, in: Bicho, N.F., Haws, J.A., Davis, L.G. (Eds.), Trekking the Shore. Springer New York, pp. 203-246.

Henderson, Z.L., 2002. A dated cache of ostrich egg flasks from Thomas' Farm, Northern Cape Province, South Africa. S Afr Archaeol Bull 57, 38-40.

Henneberg, M., Eckhardt, R.B., Chavanaves, S., Hsü, K.J., 2014. Evolved developmental homeostasis disturbed in LB1 from Flores, Indonesia, denotes Down syndrome and not diagnostic traits of the invalid species Homo floresiensis. Proc Natl Acad Sci USA 111, 11967-11972. 
Henrich, J., 2004. Demography and cultural evolution: How adaptive cultural processes can produce maladaptive losses: The Tasmanian case. Am Antiq 69, 197-214.

Henshilwood, C.S., 2005. Stratigraphic integrity of the Middle Stone Age at Blombos Cave, in: d'Errico, F., Backwell, L. (Eds.), From Tools to Symbols: From Early Hominids to Modern Humans. Witwatersrand University Press, Johannesburg, pp. 441-458.

Henshilwood, C.S., d'Errico, F., Vanhaeren, M., van Niekerk, K.L., Jacobs, Z., 2004. Middle Stone Age shell beads from South Africa. Science 304, 404.

Henshilwood, C.S., d'Errico, F., Watts, I., 2009. Engraved ochres from the Middle Stone Age levels at Blombos Cave, South Africa. J Hum Evol 57, 27-47.

Henshilwood, C.S., Sealy, J.C., Yates, R.J., Cruz-Uribe, K., Goldberg, P., Grine, F.E., Klein, R.G., Poggenpoel, C., Van Niekerk, K.L., Watts, I., 2001. Blombos Cave, southern Cape, South Africa: Preliminary report on the 1992 - 1999 excavations of the Middle Stone Age levels. J Archaeol Sci 28, 421-448.

Henshilwood, C.S., van Niekerk, K.L., Wurz, S., Delagnes, A., Armitage, S.J., Rifkin, R.F., Douze, K., Keene, P., Haaland, M.M., Reynard, J., Discamps, E., Mienies, S.S., 2014. Klipdrift Shelter, southern Cape, South Africa: preliminary report on the Howiesons Poort layers. J Archaeol Sci 45, 284303.

Jacobs, Z., Hayes, E.H., Roberts, R.G., Galbraith, R.F., Henshilwood, C.S., 2013. An improved OSL chronology for the Still Bay layers at Blombos Cave, South Africa: further tests of single-grain dating procedures and a re-evaluation of the timing of the Still Bay industry across southern Africa. J Archaeol Sci 40, 579-594.

Jacobs, Z., Roberts, R.G., Galbraith, R.F., Deacon, H.J., Grün, R., Mackay, A., Mitchell, P., Vogelsang, R., Wadley, L., 2008. Ages for the Middle Stone Age of southern Africa: implications for human behavior and dispersal. Science 322, 733-735.

Jerardino, A., 2016. On the origins and significance of Pleistocene coastal resource use in southern Africa with particular reference to shellfish gathering. J Anthropol Archaeol 41, 213-230.

Jerardino, A., Navarro, R.A., Galimberti, M., 2014. Changing collecting strategies of the clam Donax serra Röding (Bivalvia: Donacidae) during the Pleistocene at Pinnacle Point, South Africa. J Hum Evol 68, 58-67.

Joordens, J.C.A., d'Errico, F., Wesselingh, F.P., Munro, S., de Vos, J., Wallinga, J., Ankjaergaard, C., Reimann, T., Wijbrans, J.R., Kuiper, K.F., Mucher, H.J., Coqueugniot, H., Prie, V., Joosten, I., van Os, B., Schulp, A.S., Panuel, M., van der Haas, V., Lustenhouwer, W., Reijmer, J.J.G., Roebroeks, W., 2015. Homo erectus at Trinil on Java used shells for tool production and engraving. Nature 518, 228-231.

Klein, R.G., 1976. The mammalian fauna of the Klasies River Mouth sites, southern Cape Province, South Africa. S Afr Archaeol Bull 31, 75-96. 
Klein, R.G., 1989. Why does skeletal part representation differ between smaller and larger bovids at Klasies River Mouth and other archeological sites? J Archaeol Sci 16, 243-256.

Klein, R.G., 2009. The Human Career: Human Biological and Cultural Origins, Third ed. University of Chicago Press, Chicago.

Klein, R.G., Steele, T.E., 2013. Archaeological shellfish size and later human evolution in Africa. Proc Natl Acad Sci USA 110, 10910-10915.

Kyriacou, K., Parkington, J.E., Marais, A.D., Braun, D.R., 2014. Nutrition, modernity and the archaeological record: Coastal resources and nutrition among Middle Stone Age hunter-gatherers on the western Cape coast of South Africa. J Hum Evol 77, 64-73.

Kyriacou, K., Parkington, J.E., Will, M., Kandel, A.W., Conard, N.J., 2015. Middle and Later Stone Age shellfish exploitation strategies and coastal foraging at Hoedjiespunt and Lynch Point, Saldanha Bay, South Africa. J Archaeol Sci 57, 197-206.

Langejans, G.H.J., van Niekerk, K.L., Dusseldorp, G.L., Thackeray, J.F., 2012. Middle Stone Age shellfish exploitation: Potential indications for mass collecting and resource intensification at Blombos Cave and Klasies River, South Africa. Quatern Int 270, 80-94.

Lasiak, T., 1992. Contemporary shellfish-gathering practices of indigenous coastal people in Transkei: some implications for interpretation of the archaeological record. S Afr J Sci 88, 19-28.

Lombard, M., Parsons, I., 2011. What happened to the human mind after the Howiesons Poort? Antiquity 85, 1433-1443.

Manne, T., Cascalheira, J., Évora, M., Marreiros, J., Bicho, N., 2012. Intensive subsistence practices at Vale Boi, an Upper Paleolithic site in southwestern Portugal. Quatern Int 264, 83-99.

Marean, C.W., 2014. The origins and significance of coastal resource use in Africa and Western Eurasia. J Hum Evol 77, 17-40.

Marean, C.W., Bar-Matthews, M., Bernatchez, J., Fisher, E., Goldberg, P., Herries, A.L.R., Jacobs, Z., Jerardino, A., Karkanas, P., Minichillo, T., Nilssen, P.J., Thompson, E., Watts, I., Williams, H.M., 2007. Early human use of marine resources and pigment in South Africa during the Middle Pleistocene. Nature 449, 905-908.

Marean, C.W., Cawthra, H.C., Cowling, R.M., Ester, K.J., Fisher, E., Milewski, A., Potts, A.J., Singels, E., De Vynck, J., 2014. Stone Age people in a changing South African Greater Cape Floristic Region, in: Allsopp, N., Colville, J.F., Verboom, G.A. (Eds.), Fynbos: Ecology, Evolution, and Conservation of a Megadiverse Region. Oxford University Press, Oxford, pp. 104-199.

McCoy, M.D., 2008. Hawaiian limpet harvesting in historical perspective: A review of modern and archaeological data on Cellana spp. from the Kalaupapa Peninsula, Moloka'i Island. Pac Sci 62, 21-38.

Meehan, B., 1982. Shell Bed to Shell Midden. Australian Institute of Aboriginal Studies, Canberra. 
Mellars, P.A., French, J.C., 2011. Tenfold population increase in Western Europe at the Neandertal-to-Modern Human transition. Science 333, 623-627.

Montes, R., 1988. Restos malacológicos y paleontológicos del Musteriense en la costa de Murcia (Sureste de España). Anales de Prehistoria y Arqueología 4, 27-32.

Montes, R., 1991. La Cueva de los Aviones. Un yacimiento del Paleolitico Medio (Cartagena, Spain). Memorias de Arqueologia de la Region de Murcia 2, 35-58.

Morris, D., 1994. An ostrich eggshell cache from the Vaalbos National Park, Northern Cape. So. Afr. Fld Archaeol. 3, 55-589.

O'Connell, J.F., Allen, J., 2012. The restaurant at the end of the Universe: Modelling the colonisation of Sahul. Australian Archaeology 74, 5-17.

O'Connell, J.F., Allen, J., 2015. The process, biotic impact, and global implications of the human colonization of Sahul about 47,000 years ago. J Archaeol Sci 56, 73-84.

O'Connor, S., 2007. New evidence from East Timor contributes to our understanding of earliest modern human colonisation east of the Sunda Shelf. Antiquity 81, 523-535.

Outram, A.K., 2001. The scapula representation could be the key: a further contribution to the "Klasies Pattern" debate. J Archaeol Sci 28, 1259-1263.

Parkington, J.E., 2001. Milestones: the impact of the systematic exploitation of marine foods on human evolution, in: Tobias, P.V., Raath, M.A., MoggiCecchi, J., Doyle, G.A. (Eds.), Humanity from African Naissance to Coming Millennia. Witwatersrand University Press, Johannesburg, pp. 327-336.

Parkington, J.E., 2003. Middens and moderns: shellfishing and the Middle Stone Age of the Western Cape, South Africa. S Afr J Sci 99, 243-247.

Parkington, J.E., Poggenpoel, C., Rigaud, J.-P., Texier, P.-J., 2005. From tool to symbol: the behavioural context of intentionally marked ostrich eggshell from Diepkloof, Western Cape, in: d'Errico, F., Backwell, L. (Eds.), From Tools to Symbols: From Early Hominids to Modern Humans. Witwatersrand University Press, Johannesburg, pp. 475-492.

Porraz, G., Parkington, J.E., Rigaud, J.-P., Miller, C.E., Poggenpoel, C., Tribolo, C., Archer, W., Cartwright, C.R., Charrié-Duhaut, A., Dayet, L., Igreja, M., Mercier, N., Schmidt, P., Verna, C., Texier, P.-J., 2013. The MSA sequence of Diepkloof and the history of southern African Late Pleistocene populations. J Archaeol Sci 40, 3542-3552.

Powell, A., Shennan, S., Thomas, M.G., 2009. Late Pleistocene demography and the appearance of modern human behavior. Science 324, 1298-1301.

Richerson, P.J., Boyd, R., Bettinger, R.L., 2009. Cultural innovations and demographic change. Human Biology 81, 211-235.

Roebroeks, W., Soressi, M., 2016. Neandertals Revised Proc Natl Acad Sci USA 113 , in press.

Rudner, I., 1953. Decorated ostrich egg-shell and stone implements from the Upington area. S Afr Archaeol Bull 8, 82-84. 
Ruff, C.B., Trinkaus, E., Holliday, T.W., 1997. Body mass and encephalization in Pleistocene Homo. Nature 387, 173-176.

Sankararaman, S., Mallick, S., Dannemann, M., Prufer, K., Kelso, J., Pääbo, S., Patterson, N., Reich, D., 2014. The genomic landscape of Neanderthal ancestry in present-day humans. Nature 507, 354-357.

Schapera, I., 1930. The Khoisan Peoples of South Africa. Bushmen and Hottentots. G. Routledge \& Sons, Ltd, London.

Sealy, J.C., 2006. Diet, mobility, and settlement pattern among Holocene huntergatherers in southernmost Africa. Curr Anthropol 47, 569-595.

Sealy, J.C., Pfeiffer, S., 2000. Diet, body size, and landscape use among Holocene people in the Southern Cape, South Africa. Curr Anthropol 41, 642-654.

Sealy, J.C., van der Merwe, N.J., Hobson, K.A., Horton, D.R., Lewis, R.B., Parkington, J., Robertshaw, P., Schwarcz, H.P., 1986. Isotope assessment and the seasonal-mobility hypothesis in the southwestern Cape of South Africa [and comments and replies]. Curr Anthropol 27, 135150.

Speth, J.D., 2012. The Paleoanthropology and Archaeology of Big-Game Hunting: Protein, Fat, or Politics? Springer, New York.

Steele, T.E., 2012. Late Pleistocene human subsistence in northern Africa: The state of our knowledge and placement in a continental context, in: Hublin, J.-J., McPherron, S.P. (Eds.), Modern Origins. Springer Netherlands, pp. 107-125.

Steele, T.E., Alvarez-Fernández, E., 2011. Initial investigations into the exploitation of coastal resources in North Africa during the late Pleistocene at Grotte Des Contrebandiers, Morocco, in: Bicho, N.F., Haws, J.A., Davis, L.G. (Eds.), Trekking the Shore: Changing Coastlines and the Antiquity of Coastal Settlement. Springer, New York, pp. 383-403.

Steele, T.E., Klein, R.G., 2005/06. Mollusk and tortoise size as proxies for stone age population density in South Africa: implications for the evolution of human cultural capacity. Munibe 57, 221-237.

Stiner, M.C., 1993. Small animal exploitation and its relation to hunting, scavenging, and gathering in the Italian Mousterian. Archeological Papers of the American Anthropological Association 4, 107-125.

Stiner, M.C., 2009. Prey choice, site occupation intensity \& economic diversity in the Middle - early Upper Palaeolithic at the Üçağızlı Caves, Turkey. Before Farming 2009/3, Article 3.

Stoetzel, E., Campmas, E., Michel, P., Bougariane, B., Ouchaou, B., Amani, F., El Hajraoui, M.A., Nespoulet, R., 2014. Context of modern human occupations in North Africa: Contribution of the Témara caves data. Quatern Int 320, 143-161.

Straus, L.G., Bicho, N., Winegardner, A.C., 2000. The Upper Palaeolithic settlement of Iberia: First-generation maps. Antiquity 74, 553-566.

Straus, L.G., Clark, G.A., 1986. La Riera Cave: stone age hunter-gatherer adaptations in northern Spain. Arizona State University Anthropological Research Papers 36, 1-497. 
Straus, L.G., Clark, G.A., 2014. La Riera Cave: geography and culture, in: Smith, C. (Ed.), Encyclopedia of Global Archaeology. Springer New York, pp. 4353-4356.

Stringer, C.B., Finlayson, J.C., Barton, R.N.E., Fernández-Jalvo, Y., Cáceres, I., Sabin, R.C., Rhodes, E.J., Currant, A.P., Rodríguez-Vidal, J., GilesPachec, F., Riquelme-Cantal, J.A., 2008. Neanderthal exploitation of marine mammals in Gibraltar. Proc Natl Acad Sci USA 105, 14319-14324.

Sutikna, T., Tocheri, M.W., Morwood, M.J., Saptomo, E.W., Jatmiko, Awe, R.D., Wasisto, S., Westaway, K.E., Aubert, M., Li, B., Zhao, J.-X., Storey, M., Alloway, B.V., Morley, M.W., Meijer, H.J.M., van den Bergh, G.D., Grün, R., Dosseto, A., Brumm, A., Jungers, W.L., Roberts, R.G., 2016. Revised stratigraphy and chronology for Homo floresiensis at Liang Bua in Indonesia. Nature 532, 366-369.

Szabó, K., Amesbury, J.R., 2011. Molluscs in a world of islands: The use of shellfish as a food resource in the tropical island Asia-Pacific region. Quatern Int 239, 8-18.

Texier, P.-J., Porraz, G., Parkington, J.E., Rigaud, J.-P., Poggenpoel, C., Miller, C., Tribolo, C., Cartwright, C., Coudenneau, A., Klein, R., Steele, T., Verna, C., 2010. A Howiesons Poort tradition of engraving ostrich eggshell containers dated to 60,000 years ago at Diepkloof Rock Shelter, South Africa. Proc Natl Acad Sci USA 107, 6180-6185.

Thangavelu, A., David, B., Barker, B., Geneste, J.-M., Delannoy, J.-J., Lamb, L., Araho, N., Skelly, R., 2011. Morphometric analyses of Batissa violacea shells from Emo (OAC), Gulf Province, Papua New Guinea. Archaeology in Oceania 46, 67-75.

Thomas, K.D., 2015. Molluscs emergent, Part II: themes and trends in the scientific investigation of molluscs and their shells as past human resources. J Archaeol Sci 56, 159-167.

Thompson, J.C., Henshilwood, C.S., 2014. Tortoise taphonomy and tortoise butchery patterns at Blombos Cave, South Africa. J Archaeol Sci 41, 214229.

Turner, A., 1989. Sample selection, schlepp effects and scavenging: the implications of partial recovery for interpretation of the terrestrial mammal assemblage from Klasies River Mouth. J Archaeol Sci 16, 1-12.

Vaesen, K., Collard, M., Cosgrove, R., Roebroeks, W., 2016. Population size does not explain past changes in cultural complexity. Proc Natl Acad Sci USA 113, E2241-E2247.

Villa, P., Roebroeks, W., 2014. Neandertal demise: An archaeological analysis of the modern human superiority complex. PLoS ONE 9, e96424.

Villa, P., Soriano, S., Tsanova, T., Degano, I., Higham, T.F.G., d'Errico, F., Backwell, L., Lucejko, J.J., Colombini, M.P., Beaumont, P.B., 2012. Border Cave and the beginning of the Later Stone Age in South Africa. Proc Natl Acad Sci USA 109, 13208-13213.

Wadley, L., 2007. Announcing a Still Bay industry at Sibudu Cave, South Africa. J Hum Evol 52, 681-689. 
Waselkov, G.A., 1987. Shellfish gathering and shell midden archaeology. Advances in Archaeological Method and Theory 10, 93-210.

Will, M., Kandel, A.W., Kyriacou, K., Conard, N.J., 2015. An evolutionary perspective on coastal adaptations by modern humans during the Middle Stone Age of Africa. Quatern Int.

Wurz, S., 2012. The significance of MIS 5 shell middens on the Cape coast: A lithic perspective from Klasies River and Ysterfontein 1. Quatern Int 270, 61-69.

Zilhão, J., Angelucci, D.E., Badal-García, E., d'Errico, F., Daniel, F., Dayet, L., Douka, K., Higham, T.F.G., Martínez-Sánchez, M.J., Montes-Bernárdez, R., Murcia-Mascarós, S., Pèrez-Sirvent, C., Roldán-García, C., Vanhaeren, M., Villaverde, V., Wood, R., Zapata, J., 2010. Symbolic use of marine shells and mineral pigments by Iberian Neandertals. Proc Natl Acad Sci USA 107, 1023-1028. 
Shellfishing and Human Evolution - 22

\section{Figure Caption}

Figure 1. The approximate locations of the sites mentioned in the text. 


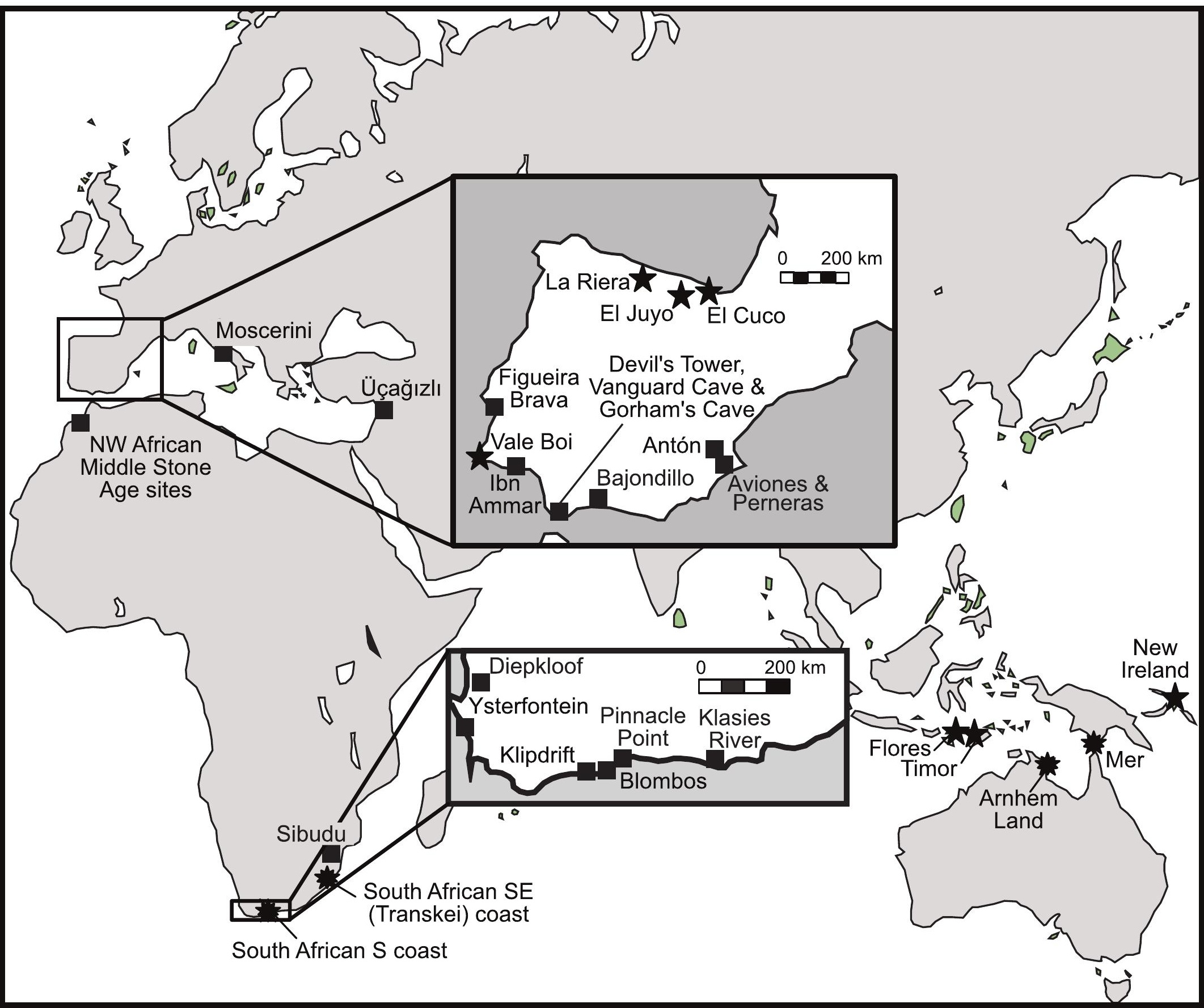

